\title{
Trophodynamics of the hyperiid amphipod Themisto gaudichaudi in the South Georgia region during late austral summer
}

\author{
E. A. Pakhomov*, R. Perissinotto \\ Southern Ocean Group, Department of Zoology \& Entomology, Rhodes University, PO Box 94, Grahamstown \\ 6140 , South Africa
}

\begin{abstract}
The feeding dynamics and predation impact of the hyperiid amphipod Themisto gaudichaudi on mesozooplankton were studied in the vicinity of South Georgia, Southern Ocean, during austral summer 1994. Data show that $T$. gaudichaudi is a visual opportunistic predator, consuming primarily the most abundant species of copepods, euphausiids and pteropods. In situ estimated daily rations were equivalent to $6.3 \%$ of body dry weight, and similar to the value of $7.1 \%$ of body dry weight derived using an energy budget approach which takes into account the total daily energy requirements. In vitro estimates produced daily rations higher than these, ranging from 8.5 to $21.8 \%$ of body dry weight, increasing with prey density. The predation impact of $T$. gaudichaudi adults, averaged over a 0 to 200 or 0 to $100 \mathrm{~m}$ layer, never exceeded $2.1 \%$ of mesozooplankton standing stock per day but accounted for up to $70 \%$ of the daily secondary production. This suggests that in the vicinity of South Georgia $T$. gaudichaudi adults are able to control the local mesozooplankton community and may contribute significantly to the downward flux of biogenic carbon
\end{abstract}

KEY WORDS: Antarctica South Georgia - Amphipods - Themisto gaudichaudi Feeding - Daily ration . Predation impact

\section{INTRODUCTION}

The hyperiid Themisto gaudichaudi is one of the most abundant pelagic amphipods of the Southern Ocean, occurring in large numbers within the subantarctic and low Antarctic zones (Hardy \& Gunther 1935, Kane 1966, Pakhomov \& McQuaid 1996). Previously regarded as a species with a bipolar distribution. in 1986 the Antarctic and the Arctic 'forms' of T. gaudichaudi were separated into 2 species by Schneppenheim \& Weigmann-Haass (1986) using morphological and electrophoretic evidence. Several feeding studies with $T$. gaudichaudi (now $T$. compressa) and with other members of the genus Themisto have been carried out in the northern hemisphere (Sheader \& Evans 1975, Yamashita et al. 1984, 1985, Persy 1993). Although it is generally assumed (Ikeda 1989) that results obtained

\footnotetext{
·E-mail:zoep@warthogru.ac.za
}

with the northern hemisphere species may be applicable to the ecologically similar species of the Southern Ocean, independent estimates of daily ration and predation impact of $T$ gaudichaudi in Antarctic waters are still not available.

Amphipods of the genus Themisto are generally regarded as obligate carnivorous species (Kane 1967. Sheader \& Evans 1975, Hopkins 1985) and are also known to form parasitic/parasitoid associations with gelatinous zooplankton like salps and medusae (Madin \& Harbison 1977, Laval 1980). There are however some indications that they may consume phytoplankton cells as well, especially in the early stages of development (Siegfried 1965, Nemoto \& Yoo 1970, Hopkins 1985, Sugisaki et al. 1991). T. gaudichaudi has a high energy content (Williams \& Robins 1979, Strelnikova 1989, Torres et al. 1994b) and is one of the main food sources for many predators including fish, squid, birds and whales (Nemoto \& Yoo 1970, Permitin \& Tarverdieva 1972, Chechun 1984, Rodhouse et al. 1992, Bost 
et al. 1994, Kock et al. 1994). Thus, T. gaudichaudiconstitutes an important ecological link between small zooplankton and top consumers and, in certain areas, may effectively control the mesozooplankton standing stock (Gibbons et al. 1992) and affect the population dynamics of predators such as penguins (Bost et al. 1994) and fish (Kock et al. 1994). T. gaudichaudi may also contribute substantially to the downward carbon flux in the subantarctic zone due to its high abundances, marked diel vertical migrations (Kane 1966, Everson \& Ward 1980) and production of fast-sinking faecal pellets (Fortier et al. 1994).

Themisto gaudichaudi is the dominant pelagic amphipod in the waters surrounding South Georgia, where it often occurs in dense swarms (Hardy \& Gunther 1935, Atkinson \& Peck 1988). Nevertheless, feeding studies on this species have never been undertaken in the region. The main aim of this paper is, therefore, to provide some estimates of daily ration and predation impact of $T$. gaudichaudi on the mesozooplankton community of South Georgia.

\section{MATERIALS AND METHODS}

Sampling strategy. Specimens of Themisto gaudichaudi were obtained from general zooplankton samples and from tows of krill trawls made during voyage 119 of the RV 'Africana' in February-March 1994 near South Georgia (Fig, 1). During the survey, zooplankton was sampled using Bongo and WP-2 nets with a mouth area of $0.5 \mathrm{~m}^{2}$ and a mesh size of $0.3 \mathrm{~mm}$. Both nets were fitted with a Universal Underwater Unit (Robertson et al. 1981). The volume filtered by the Bongo net was calculated using electronic flowmeter (General Oceanics, Miami, FL, USA) data, while for the WP-2 this was determined by multiplying the mouth area by the distance sampled. Bongo nets were towed obliquely between 0 and $200 \mathrm{~m}$ while 0 to $100 \mathrm{~m}$ vertical hauls were made with the WP-2 net. In addition, collections with a Neuston net (mesh size $0.8 \mathrm{~mm}$ ) were obtained on 2 occasions by towing at the surface for -30 min during darkness. Specimens of $T$. gaudichaudi for gut content analysis were also taken from krill samples collected with the Polish Krill Trawl 1641 (mesh size of $7 \mathrm{~mm}$ ). Trawls were towed obliquely between the surface and $\sim 100 \mathrm{~m}$ depth and, on a few occasions, as close as possible to the shelf bottom. All samples were preserved in 4 to $6 \%$ buffered formalin and examined in the laboratory.

Length-weight relationships. Three to 25 preserved individuals Themisto gaudichaudi were taken from each sample for length-weight analyses. Three different body length measurements were undertaken with an accuracy of $\sim 0.01 \mathrm{~mm}$ : from the anterior part of the head, excluding the antenna, to the end of the uropods $\left(L_{1}\right)$; to the tip of the telson $\left(L_{2}\right)$; and to the end of the thorax $\left(L_{3}\right)$. After measurements, each animal was dried on filter paper and its wet weight determined with an accuracy of $\sim 0.1 \mathrm{mg}$. Dry weight was estimated by weighing hyperiids oven-dried at $60^{\circ} \mathrm{C}$ for $36 \mathrm{~h}$.

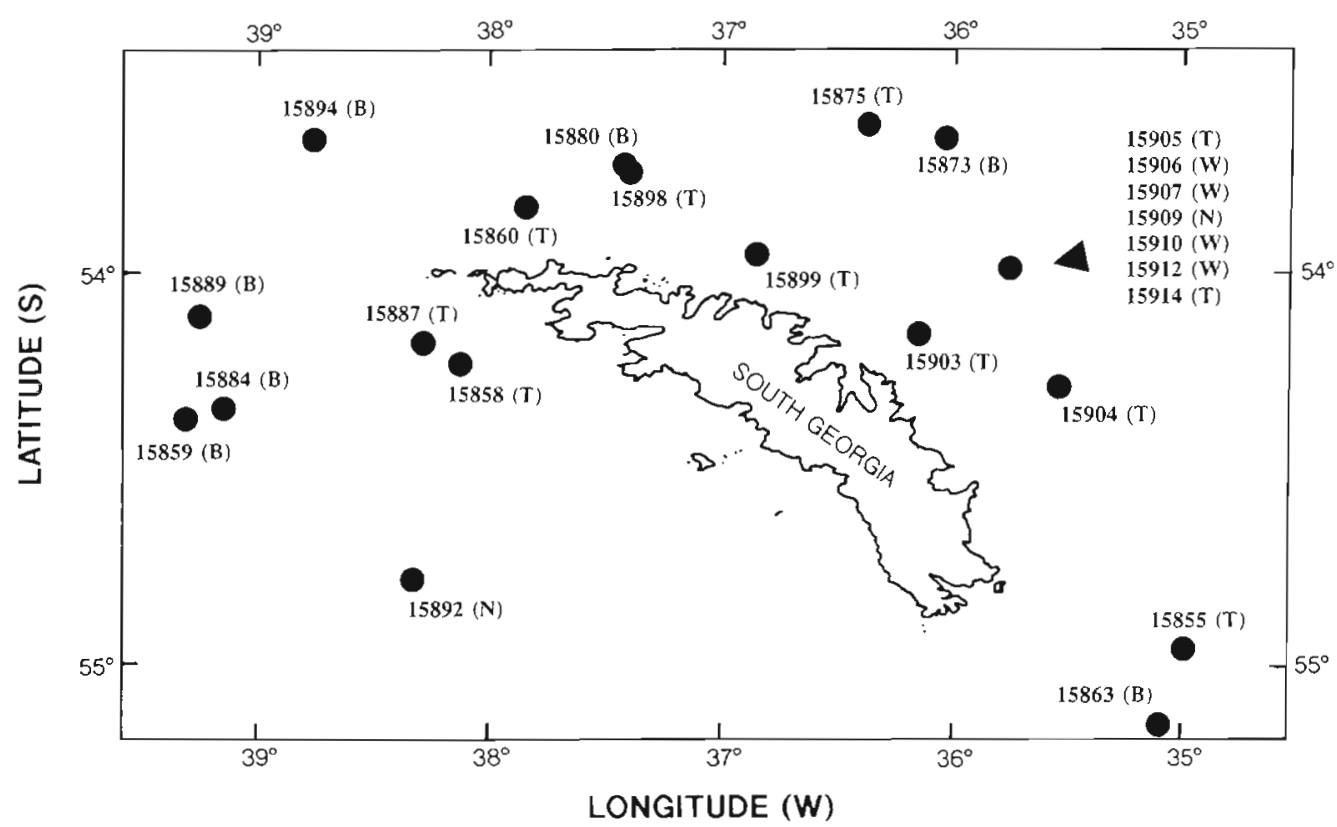

Fig. 1. Position of sampling stations in the vicinity of South Georgia during February-March 1994. Samples were collected using either a Bongo net (B), a WP-2 net (W), a Neuston net (N) or a Polish Krlll Trawl (T) 
Gut content analysis. From 4 to 25 (depending on total sample size) preserved Themisto gaudichaudi from each tow were examined for gut contents. Hyperiids were first measured from the anterior part of the head to the end of the thorax. After their gut content was removed, animals were oven-dried at $60^{\circ} \mathrm{C}$ for $36 \mathrm{~h}$. Prey items were isolated from stomachs and, where possible, identified to species level. One to 5 gut contents, depending on stomach fullness, were then collected onto a preweighed GF/F filter and dried at $60^{\circ} \mathrm{C}$ for $24 \mathrm{~h}$. All results from the stomach content analysis were expressed as frequency of occurrence $(\%)$ of each item in stomachs with food. The index of stomach fullness, expressed as percentage of body weight, was calculated by dividing the dry weight of the stomach contents by the dry weight of the hyperiid body.

Gut pigment contents and evacuation rate experiments. From each tow, modal-sized Themisto gaudichaudi were taken immediately after capture. One to 6 replicate animals were placed in plastic centrifuge tubes (one per tube) with $5 \mathrm{ml}$ of $100 \%$ methanol and stored at $-20^{\circ} \mathrm{C}$ for $12-24 \mathrm{~h}$ (Simard et al. 1985). After centrifugation $(1745 \times g)$, the pigment content of the methanol extract was measured with a Turner $111 \mathrm{flu}$ orometer, before and after acidification (Mackas \& Bohrer 1976). Pigment contents were expressed in terms of total pigments per individual and calculated according to Strickland \& Parsons (1968) as modified by Conover et al. (1986).

To estimate the gut evacuation rate constant $(k)$, freshly caught and healthy, modal-sized $T$. gaudichaudi were taken from the 31 cod-end of the Bongo net and placed into 201 containers with filtered seawater. Containers with experimental animals were kept on deck at ambient temperature. Experiments were run for $-8 \mathrm{~h}$ and the decline in gut content was monitored at intervals of 15 to $30 \mathrm{~min}$, for the first $3 \mathrm{~h}$, and of 1 to $2 \mathrm{~h}$ thereafter. Gut evacuation rate $\left(k, \mathrm{~h}^{-1}\right)$ was derived from the slope of the regression of the natural logarithm of gut pigments versus time (Dam \& Peterson 1988).

Estimation of daily ration. Daily ingestion rates of Themisto gaudichaudi $\left(C_{\mathrm{w}}\right)$ were estimated from the relation: $C_{w}=G \times 24 \times k$, where $k$ is the gut evacuation rate constant in $\mathrm{h}^{-1}$ and $G$ is the average value of the $24 \mathrm{~h}$-integrated (day-cycle) index of stomach fullness in $\%$ of body dry weight. Another estimate of daily ration was obtained using an energy budget approach, based on estimates of hyperiid metabolic energy requirements and Net Conversion Efficiency, $K_{2}=$ $P /(P+R)$, where $P$ is production and $R$ is the metabolic energy demands. $K_{2}$ values for pelagic zooplankton species range from 0.2 to 0.5 and for adults are usually equal to $\sim 0.3$ (Vinogradov \& Shushkina 1987). Thus,
$P=0.43 \times R$. The food intake is: $C=P+R / U$, where $U$ is the assimilation coefficient (Vinberg 1956). Assuming $U \sim 0.8$ (Vinogradov \& Shushkina 1987), a value for $C$ of $\sim 1.79 \times R$ is derived. Under natural conditions, $R$ is equal to $\sim 2 \times R_{\mathrm{bw}}$, where $R_{\mathrm{bw}}$ represents the basic metabolic needs during winter. According to estimates obtained by Torres et al. (1994a, b), $1 \mathrm{~g}$ wet weight of T. gaudichaudi contains $687 \mathrm{cal}$ and $R_{\mathrm{bw}}=0.133 \mu \mathrm{O} \mathrm{O}_{2}$ $\mathrm{mg}^{-1}$ wet weight $\mathrm{h}^{-1}$, or (using average wet weight of $T$. gaudichaudi: $0.073 \mathrm{~g}) 0.233 \mathrm{ml} \mathrm{O}_{2}$ ind $^{-1} \mathrm{~d}^{-1}$ Assuming $1 \mathrm{ml} \mathrm{O}=4.86 \mathrm{cal}=7.07 \mathrm{mg}$ wet weight of $T$. gaudichaudi, $R$ can be estimated by doubling the basic metabolic requirements: $R=2 \times R_{\mathrm{bw}}=2 \times 0.233 \times$ $0.00707 \times 100 / 0.073=4.51 \%$ of body wet weight.

Predation experiments. Three separate predation experiments were conducted during the cruise period. Hyperiids were obtained from 0 to $200 \mathrm{~m}$ oblique Bongo tows and only active and undamaged individuals from the 31 open cod-end were used. Prior to each experiment, Themisto gaudichaudi were kept for 24 to $26 \mathrm{~h}$ in $20 \mathrm{l}$ containers filled with filtered seawater. For each experiment, water containing zooplankton previously screened through a $1 \mathrm{~mm}$ (Expts 1 and 3 ) or $3 \mathrm{~mm}$ (Expt 2) mesh was mixed in $20 \mathrm{l}$ buckets and then used to fill one $2 \mathrm{l}$ (experimental) and three $1 \mathrm{l}$ (control) volume plastic jars. Three initial (control jars) subsamples of 11 each were concentrated and preserved in $4 \%$ buffered formalin. Experimental animals were then gently transferred to the 2 l jars (4 or 5 animals per jar) and incubated for $\sim 24 \mathrm{~h}$ to integrate any diel feeding activity which may occur in nature. Experimental jars were kept on deck at ambient temperature and $-50 \%$ of ambient light intensity, and agitated constantly by keeping them in a circulating bath. At the end of the experiment, the content of the experimental jars was concentrated and preserved in $4 \%$ buffered formalin. In the laboratory, all zooplankton were measured with an accuracy of $\sim 0.5 \mathrm{~mm}$, identified to genus level and counted. After this, the dry weights of the zooplankton in the control bottles, of those remaining in the experimental jars and of $T$ gaudichaudi were measured by oven-drying the samples at $60^{\circ} \mathrm{C}$ for $36 \mathrm{~h}$

\section{RESULTS}

\section{Length-weight relationships}

Due to a lack in the literature of empirical relationships between the different types of length measurements generally used $\left(L_{1}, L_{2}\right.$ and $\left.L_{3}\right)$, regressions between them were calculated in this study (Table 1 ). Linear regression models were highly significant $(\mathrm{p}<$ 0.001 ) and provided the best fit to the data, explaining 
Table 1 Themisto gaudichaudi $(\mathrm{N}=69)$. Regression coefficients for the relationships between different length measurements $\left(L_{1}, L_{2}, L_{3}\right.$, in $\mathrm{mm}$ ), wet (WW, in mg) and dry (DW, in $\mathrm{mg}$ ) body weights. All regressions are significant at $p<0.001$

\begin{tabular}{|lccc|}
\hline Type of regression & $a$ & $b$ & $\mathrm{r}$ \\
\hline$y=a+b x$ & & & \\
$L_{1}$ vs $L_{2}$ & -1.532 & 1.414 & 0.988 \\
$L_{1}$ vs $L_{3}$ & -0.837 & 2.836 & 0.974 \\
$L_{1}$ vs $L_{3}$ & 0.475 & 2.008 & 0.986 \\
DW vs WW & 1.485 & 0.144 & 0.915 \\
$y=a x^{\mathrm{b}}$ & & & \\
DW vs $L_{1}$ & 0.002 & 2.804 & 0.941 \\
DW vs $L_{2}$ & 0.0023 & 3.030 & 0.955 \\
DW vs $L_{3}$ & 0.0215 & 3.017 & 0.958 \\
WW vs $L_{1}$ & 0.020 & 2.646 & 0.973 \\
WW vs $L_{2}$ & 0.025 & 2.830 & 0.977 \\
WW vs $L_{3}$ & 0.195 & 2.824 & 0.982 \\
\end{tabular}

$>90 \%$ of the total variance. The average water content of individual Themisto gaudichaudi was $16.7 \pm 3.4 \%$ of the total wet weight. Generally, water content showed an inverse linear correlation with hyperiid size (Table 1). Weight versus length regressions were in the form of a power function and highly significant $(p<$ 0.001 ), explaining over $85 \%$ of total variance (Table 1 ).

\section{Gut content analyses}

Themisto gaudichaudi individuals used for gut content analysis ranged in size from 6 to $10 \mathrm{~mm}$ thorax length $\left(L_{3}\right)$, with a modal size of 7 to $8 \mathrm{~mm}$ (Fig. 2). Average wet and dry weights were 0.073 and $0.012 \mathrm{~g}$, respectively.

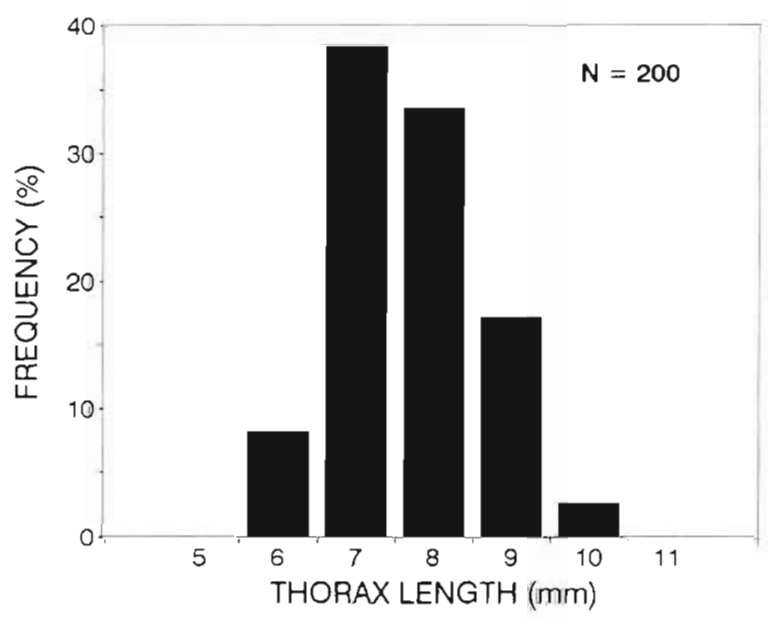

Fig. 2. Themisto gaudichaudi. Size-frequency distribution of hyperiids used in the gut content analysis
Copepods were the dominant components of the diet of Themisto gaudichaudi at almost all stations, accounting for 10 to $100 \%$ (mean $69.2 \%$ ) of the total prey occurrence in stomachs (Table 2). Among them, Calanus simillimus, Calanoides acutus and Metridia spp. were found most often. The next most abundant prey were euphausiids, mainly furcilia stages of Euphausia spp. and Thysanoessa spp., which accounted for up to $50 \%$ of the total food items identified in those stomachs with food. The pteropod Limacina spp. formed the bulk of $T$. gaudichaudi diet at least at 2 stations where it constituted up to 50 to $100 \%$ of the total food items consumed (Table 2). Ostracods, polychaetes and chaetognaths were found only occasionally in the stomachs of $T$. gaudichaudi.

The mean index of stomach fullness ranged widely, from 0.26 to $4.54 \%$ of the dry body weight (Table 2). Highest levels coincided with samples in which the lowest proportions of empty stomachs of Themisto gaudichaudi were recorded. Indices of stomach fullness monitored throughout a $24 \mathrm{~h}$ day-cycle exhibited highest levels in the early morning hours, just after sunrise, and during the afternoon before sunset (Fig. 3). Based on the data presented in Fig. 3, the average index of stomach fullness integrated over a $24 \mathrm{~h}$ day-cycle $(G)$ was $1.96 \%$ of body dry weight.

Individual levels of gut pigment concentration of Themisto gaudichaudi estimated fluorometrically varied markedly, ranging from 4 to $577 \mathrm{ng}$ (pigm.) ind.-1 (Fig. 3). The highest levels of gut pigment contents were recorded in the late afternoon (13:00 to 18:00 h GMT) (Fig. 3).

All data obtained from the gut evacuation experiments were best fitted by a negative exponential model of gut pigment content versus time (Fig. 4). The values of gut evacuation rate constant $(k)$ and gut turnover time $(1 / k)$ calculated from the model fit were $0.133 \mathrm{~h}^{-1}$ and $7.5 \mathrm{~h}$, respectively.

\section{Daily rations}

Using the $k$ and $G$ values calculated above, the daily food intake of Themisto gaudichaudi adults was estimated as: $C_{w}=1.96 \times 24 \times 0.133=6.3 \%$ of body dry weight. This is also equivalent to body $C$ as the carbon content of the main food items and of $T$. gaudichaudi adults are very similar (Ikeda \& Mitchell 1982, Torres et al. 1994b).

The second approach is based on estimates of the metabolic requirements of Themisto gaudichaudi and of its $K_{2}$. According to these, $C_{w}=1.79 \times R=8.08 \%$ of body wet weight. Since the energy spent on reproduction by crustaceans accounts for $\sim 16 \%$ of the total daily ration (Tseitlin 1988), $C_{w}$ would then increase to $9.37 \%$ 


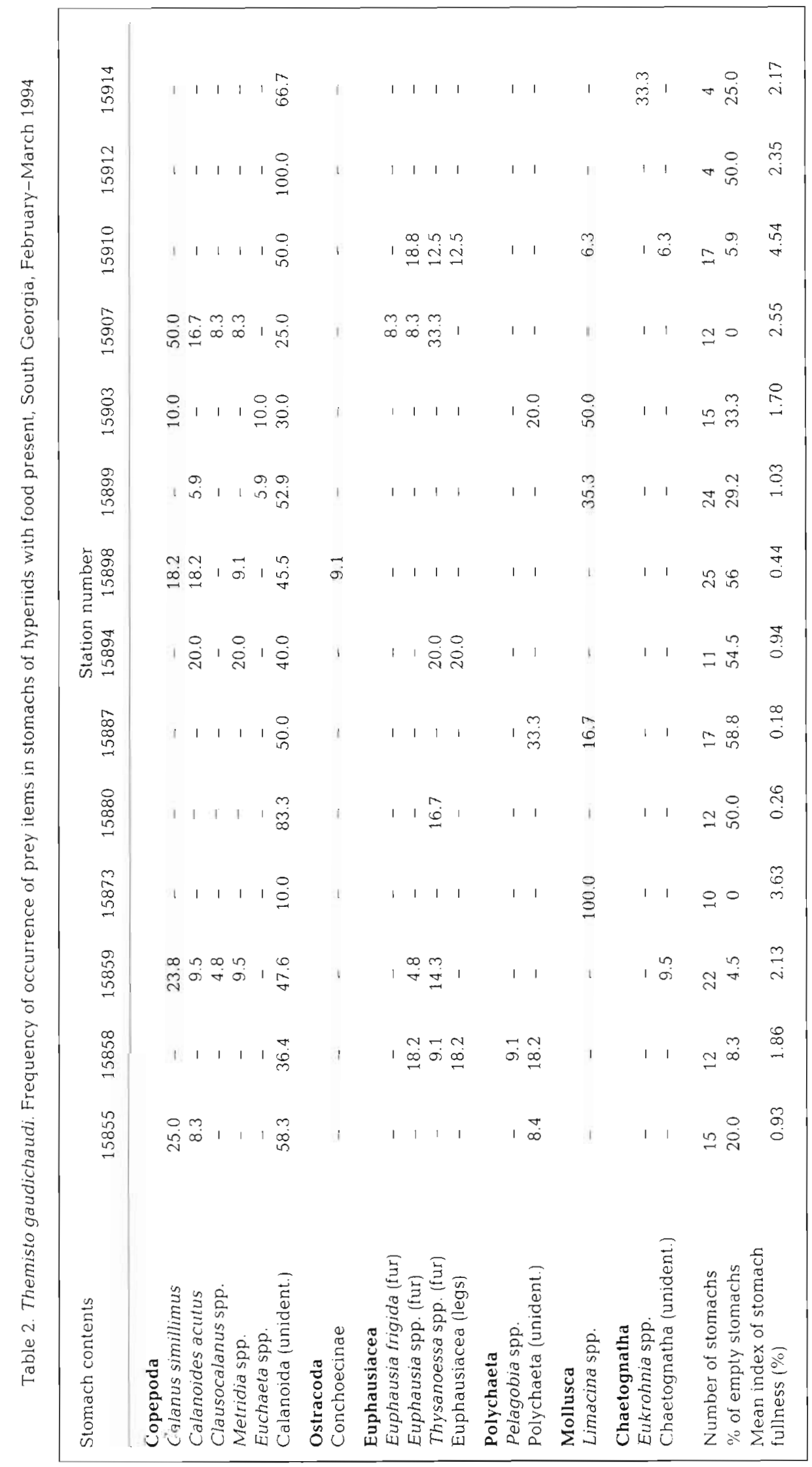



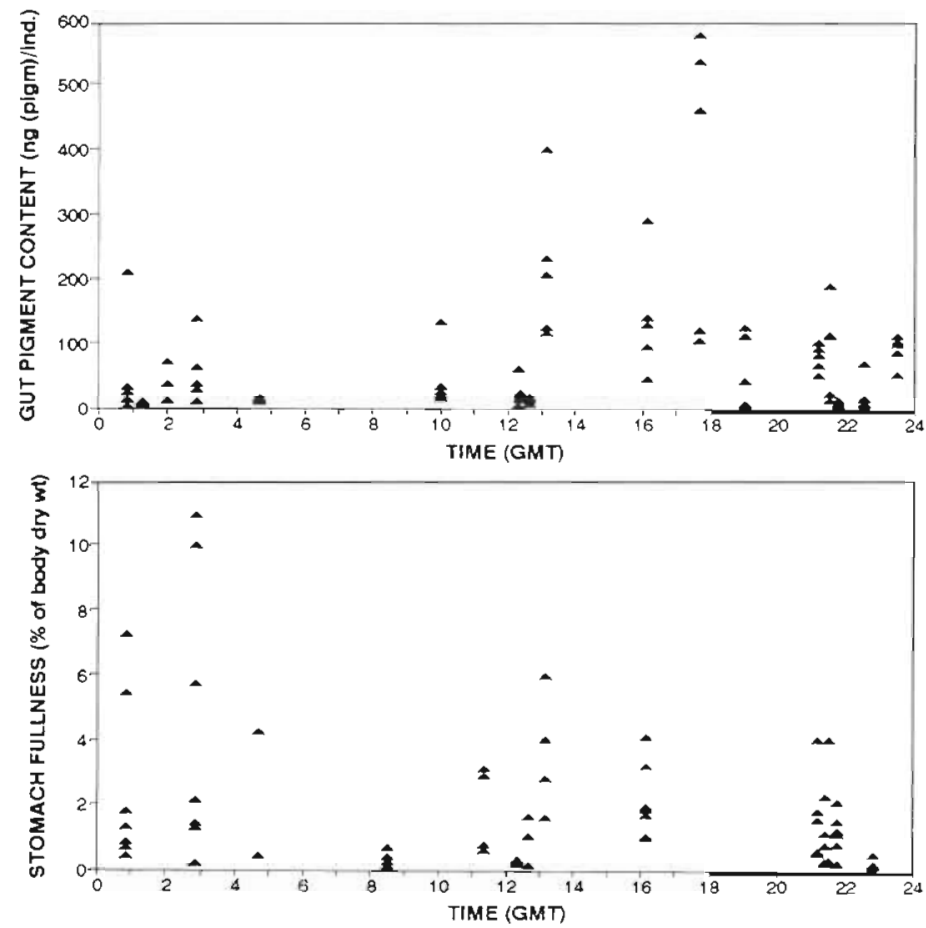

Fig. 3. Themisto gaudichaudi. Diurnal variations in total gut pigment contents and in the index of stomach fullness of hyperiids around South Georgia during austral summer 1994. Period of darkness is indicated by thickening of the horizontal axis

of wet body weight. Considering further a discrepancy between the average dry weight of Themisto gaudichaudi (16.7\% of wet weight) and of its main food items $(-22 \%$ of wet weight), the daily ration of $T$. gaudichaudi adults would be equal to $7.1 \%$ of body dry weight.

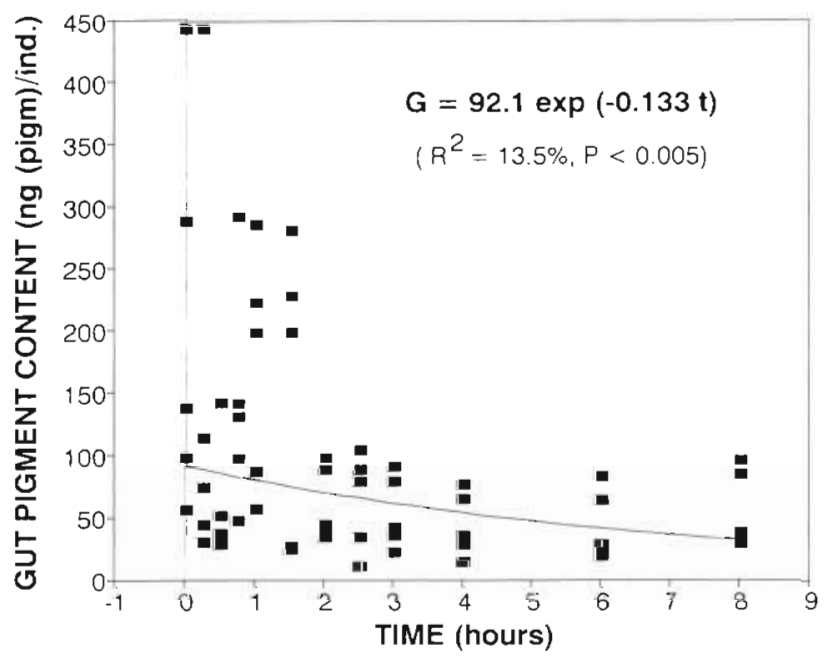

Fig. 4. Themisto gaudichaudi. Gut evacuation rate of adults collected in the vicinity of South Georgia during February 1994
The results of the predation experiments are presented in Fig. 5 and Table 3. Themisto gaudichaudi adults preferentially consumed prey in the size range of 1 to $4 \mathrm{~mm}$. However, furcilia and juvenile stages of euphausiids, with total length of 9 to $13 \mathrm{~mm}$, were also consumed very efficiently (Fig. 5, Expt 2). No feeding selectivity between different genera exhibiting the same size was observed. Daily rations of $T$. gaudichaudi increased with the increase in prey density, from 8.5 to $21.8 \%$ of body dry weight in experimental jars with initial prey density of 354 and 1917 ind. $1^{-1}$, respectively (Table 3 , Fig 5).

\section{Predation impact}

To examine the predation impact of Themisto gaudichaudi adults, we used data on mesozooplankton biomass (including copepods, ostracods, euphausiids $<15 \mathrm{~mm}$, pteropods, chaetognaths and polychaetes) collected during the same cruise and derived from 0 to $200 \mathrm{~m}$ oblique Bongo and 0 to $100 \mathrm{~m}$ vertical WP-2 net tows ( $\mathrm{H}$. Verheye unpubl. data). Abundance and biomass of $T$ gaudichaudi estimated from these samples varied markedly, ranging from 0 to 305 ind. $\mathrm{m}^{-2}$ and from 0 to $2.8 \mathrm{~g}$ dry weight $\mathrm{m}^{-2}$, respectively (Table 4 ).

The calculated daily predation rates were generally low, accounting for $<0.4 \%$ and $<13 \%$ of mesozooplankton standing stock and secondary production, respectively (Table 4). Only at 3 out of the 10 stations sampled was predation impact substantially higher than 1\% (range: 1 to $2.1 \%$ ) of mesozooplankton standing stock and higher than 30\% (range: 32 to $70 \%$ ) of secondary production per day. Generally, impact was highest at stations where the highest densities of Themisto gaudichaudi (Stn 15859) Cooccurred with the lowest zooplankton abundances (Stns 15910 and 15912) (Table 4).

\section{DISCUSSION}

\section{Feeding ecology}

The results of the gut content analysis show a close relationship between the structure of the local zooplankton community and the diet composition of Themisto gaudichaudi. The most abundant species of copepods, euphausiids and pteropods collected with net tows around South Georgia formed the bulk of the diet of $T$ gaudichaudi adults during austral summer 1994. Previously published data (Siegfried 1965. 

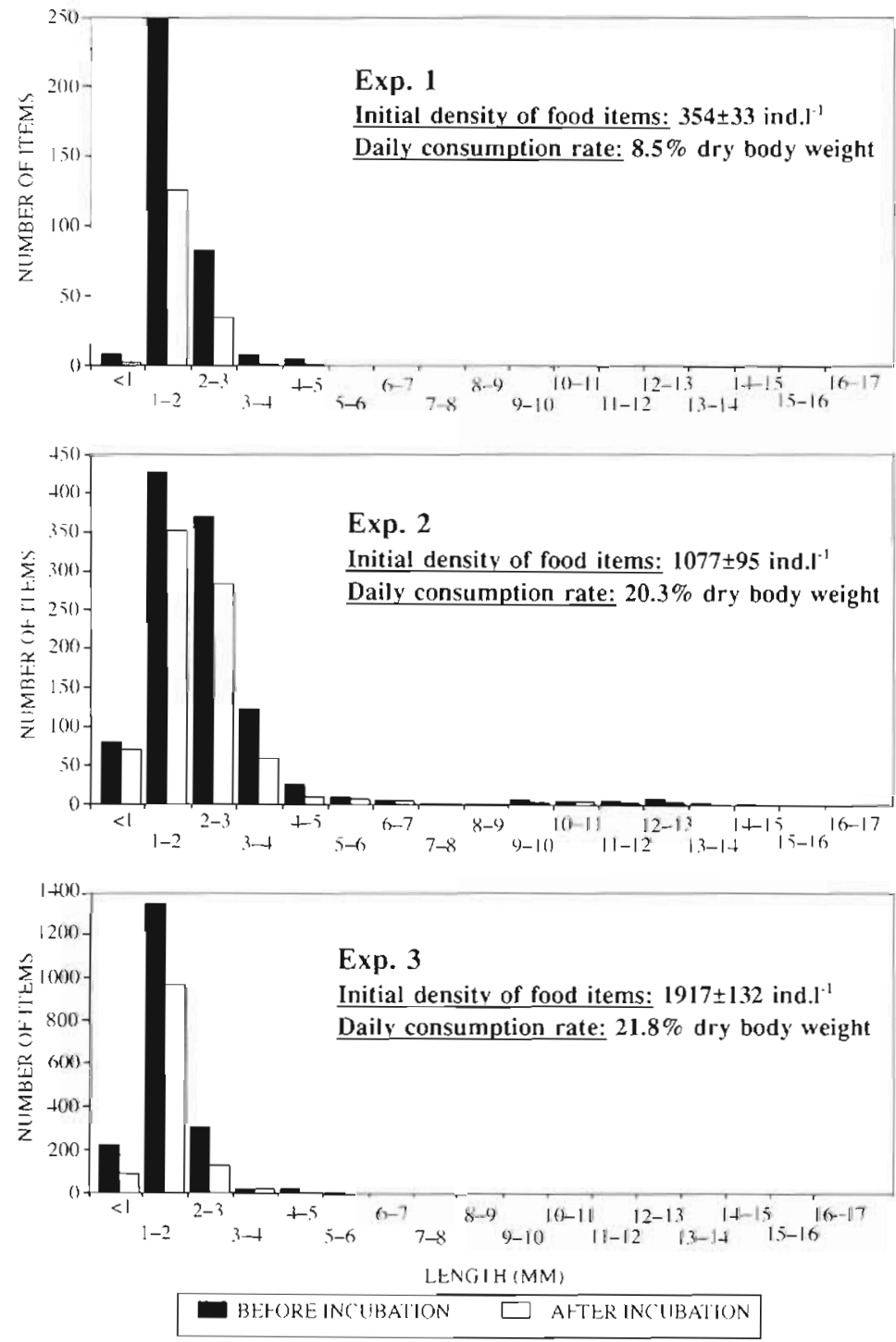

Fig. 5. Themisto gaudichaudi. Size-frequency distribution of the prey items of hyperiids used in the predation experiments

Nemoto \& Yoo 1970, Hopkins 1985) and the results of our predation experiments confirm the hypothesis that T. gaudichaudi is an opportunistic predator with the capability of consuming any prey of appropriate size and taxonomy (Gibbons et al. 1992). It has also been shown that phytoplankton may play a substantial role in the feeding budget of young I gaudichaudi (Siegfried 1965, Nemoto \& Yoo 1970, Hopkins 1985). Large amounts of phytoplankton pigments were recovered in the guts of $T$ gaudichaudi adults during this study but it was not possible to show, with our technique, whether the phytoplankton cells originated from consumed prey or were ingested directly by the hyperiid.

It has been clearly shown in Themisto japonica that gut pigment concentrations of young hyperiids are significantly higher than those of larger specimens (Sugisaki et al. 1991). This suggests that the feeding behaviour of $T$. japonica switches from herbivory to carnivory during its life-cycle. The same has also been proposed for $T$. gaudichaudi in the Benguela Upwelling System (Siegfried 1965). Only adults of $T$. gaudichaudi were analyzed in our study and no identifiable phytoplankton cells were recovered from their stomachs. Thus, the occurrence of sizable levels of pigments in their guts suggests that the phytoplankton material is most likely of secondary derivation, e.g. pigments extracted from guts of $T$ gaudichaudi prey. This hypothesis is supported by the close covariance between maximum gut pigment levels and total gut contents observed during a 24 h day-cycle (Fig. 3).

The gut pigment content data show only 1 clear peak in the diurnal feeding activity of Themisto gaudichaudi adults, while the stomach fullness indices exhibit 2 distinct peaks. Since pigments in the gut of T. gaudichaudi have a secondary origin, this discrepancy is probably the result of the diel periodicity in the feeding pattern of the hyperiid preys. The 2 peaks coincided with the periods just after sunrise and before sunset, reflecting the well-known pattern of diurnal vertical migration of $T$. gaudichaudi (Hardy \& Gunther 1935, Kane 1966, Everson \& Ward

Table 3. Themisto gaudichaudi. Results of predation experiments with different prey concentrations

\begin{tabular}{|c|c|c|c|c|c|c|c|}
\hline $\begin{array}{l}\text { Expt } \\
\text { no. }\end{array}$ & \multicolumn{2}{|c|}{ Themisto gaudichaudi } & \multicolumn{2}{|c|}{ Initial prey density $( \pm S D)$} & \multicolumn{2}{|c|}{ Final prey density } & $\begin{array}{l}\text { Daily ration } \\
\text { (\% body DW) }\end{array}$ \\
\hline 1 & 4 & 62.5 & $354 \pm 33$ & $14.2 \pm 1.3$ & 165 & 8.9 & 8.5 \\
\hline 2 & 5 & 140.7 & $1077 \pm 95$ & $150.4 \pm 13.3$ & 806 & 121.8 & 20.3 \\
\hline 3 & 4 & 85.7 & $1917 \pm 132$ & $65.5 \pm 4.5$ & 1205 & 46.8 & 21.8 \\
\hline
\end{tabular}


Table 4. Themisto gaudichaudi. Predation impact on mesozooplankton standing stock in the vicinity of South Georgia during February-March 1994. Zooplankton biomass was estimated from oblique Bongo and vertical WP-2 net tows (H. Verheye unpubl. data). The daily ration of adults was assumed to be equal to $6.3 \%$ body dry weight. Secondary production rates were obtained from the $P / B$ (production/biomass) coefficients $\left(\sim 3 \% \mathrm{~d}^{-1}\right)$ for mesozooplankton available in the literature (Vinogradov \& Shushkina 1987 )

\begin{tabular}{|c|c|c|c|c|c|c|}
\hline \multirow[t]{2}{*}{ Stn no. } & \multirow{2}{*}{$\begin{array}{l}\text { Mesozooplankton } \\
\text { biomass } \\
\text { (g DW m }{ }^{-2} \text { ) }\end{array}$} & \multirow{2}{*}{$\begin{array}{l}\text { Daily } 2 \text { nd } \\
\text { production } \\
\left(g \mathrm{DW} \mathrm{m}^{-2}\right)\end{array}$} & \multicolumn{2}{|c|}{ Themisto gaudichaudi } & \multicolumn{2}{|c|}{ Predation impact } \\
\hline & & & $\begin{array}{l}\text { Abundance } \\
\text { (ind. } \mathrm{m}^{-2} \text { ) }\end{array}$ & $\begin{array}{c}\text { Biomass } \\
\left(g \mathrm{DW} \mathrm{m}^{-2}\right)\end{array}$ & $\begin{array}{c}\% \\
\text { biomass }\end{array}$ & $\begin{array}{l}\% \text { 2nd } \\
\text { production }\end{array}$ \\
\hline 15859 & 8.419 & 0.252 & 305.0 & 2.806 & 2.10 & 70.2 \\
\hline 15863 & 15.151 & 0.454 & 66.5 & 0.796 & 0.33 & 11.0 \\
\hline 15873 & 25.566 & 0.767 & 42.6 & 0.510 & 0.13 & 4.2 \\
\hline 15880 & 6.806 & 0.204 & 34.4 & 0.412 & 0.38 & 12.7 \\
\hline 15884 & 9.510 & 0.274 & 0.8 & 0.010 & $<0.01$ & 0.2 \\
\hline 15889 & 7.506 & 0.225 & 0 & 0 & 0 & 0 \\
\hline 15894 & 5.196 & 0.156 & 13.0 & 0.104 & 0.19 & 6.4 \\
\hline 15907 & 3.655 & 0.109 & 47.1 & 0.564 & 0.96 & 32.1 \\
\hline 15910 & 4.325 & 0.130 & 78.4 & 0.940 & 1.36 & 45.4 \\
\hline 15912 & 6.987 & 0.210 & 15.7 & 0.188 & 0.17 & 5.7 \\
\hline
\end{tabular}

1970). According to this pattern, maximum feeding activity would be observed when hyperiids rise towards the surface to feed and when they sink to depth in the early morning hours. From in vitro experiments with $T$. japonica, Yamashita et al. (1984) showed that hyperiids are able to continue feeding in darkness. Our results partly confirm this observation (Fig. 3) but the occurrence of all major feeding peaks during daylight hours suggests that $T$. gaudichaudi is an active visual predator (Gibbons et al. 1992).

The gut passage time obtained from the gut evacuation rate experiments was equal to $-7.5 \mathrm{~h}$. This value, however, should be considered with great care as 2 independent processes may have affected the results substantially. Firstly, gut passage time $(1 / k)$ was estimated in a container filled with filtered seawater. This may have caused an underestimation of $1 / \mathrm{K}$ values because Themisto gaudichaudi adults can retain food in their stomachs for period longer than $24 \mathrm{~h}$ in the absence of food (Gibbons et al. 1992). Secondly, we did not estimate the rate of destruction of the secondary pigments in the gut during digestion. Up to 50 to $90 \%$ of total pigments ingested by herbivorous zooplankton may be broken down in the gut to non-fluorescent end-products (Lopez et al. 1988, Mayzaud \& Razouls 1992, Perissinotto \& Pakhomov in press). In contrast to the first problem, this may result in an overestimation of the gut passage time. Unfortunately, the magnitude of these 2 separate factors is unknown and it is not impossible that they may compensate for each other. Also, the level of gut pigment destruction in $T$. gaudichaudi adults may even be negligible because the digestive enzyme system of this carnivorous stage of the species is probably not capable of digesting plant pigments. A comparison of the $k$-value obtained in our study, $0.133 \mathrm{~h}^{-1}$, with those of other crustaceans reported in the literature, indicates that this is very similar to the $k$-values for Euphausia superba, 0.101 to $0.424 \mathrm{~h}^{-1}$ (Perissinotto \& Pakhomov in press) and of $T$. japonica, $k=0.154 \mathrm{~h}^{-1}$, at $\mathrm{T}=6^{\circ} \mathrm{C}$ (Yamashita et al. 1985). Considering all these points, it is not unreasonable to assume that the gut evacuation rate constant and passage time obtained in this study are close to the real values.

\section{Daily ration}

To date, very little is known about the rate of daily food consumption by Themisto gaudichaudi. According to estimates of the oxygen consumed by $T$. gaudichaudi adults obtained by Torres et al. (1994a), the Minimum Food Intake (MFI) that covers the demands for respiration only is $\sim 1.71 \%$ of the body dry weight. This value is very similar to the MFI levels of 1.07 to $2.16 \%$ of body carbon calculated by Ikeda \& Mitchell (1982), and slightly higher than the respiration losses (1.0 to $1.2 \%$ of body weight) obtained for the amphipod T. libellula during long-term starvation (Persy 1993). The only thorough study of this type has been undertaken with $T$. compressa (formerly $T$. gaudichaudi) in the northern hemisphere (Sheader \& Evans 1975). Daily rations derived from these data range from 2.7 to $6.0 \%$ of body dry weight. In a study of the in situ feeding ecology of $T$. japonica (Yamashita et al 1985), daily rations ranged between 4.3 and $10.9 \%$ (mean $\pm \mathrm{SD}=8.64 \pm 1.92 \%$ ) of body dry weight.

The in situ daily ration estimated in our study $(6.3 \%$ of body dry weight) is at least 3.7 times higher than the MFI level and comparable to the values derived from other species of the genus Themisto. This estimate is also in good agreement with the daily rations calcu- 
lated using the total energy requirements approach (7.1\% of body dry weight). Rations obtained from the predation experiments were, however, generally higher, ranging from 8.5 to $21.8 \%$ of body dry weight. These are more comparable to the daily rations obtained in vitro with $T$. japonica, of 15.4 to $24.2 \%$ (mean $20.3 \%$ ) of dry body weight (Yamashita et al. 1984).

The lowest of these estimates, $8.5 \%$ of dry body weight, exceeds the in situ ration by $25 \%$ only and was derived from an experiment involving an initial prey concentration of 354 ind. $\mathrm{I}^{-1}$. According to data derived from Bongo and WP-2 net catches (H. Verheye unpubl.), zooplankton abundances averaged over the 0 to 200 or the 0 to $100 \mathrm{~m}$ layers ranged from 0.08 to 0.52 ind. $\mathrm{I}^{-1}$ (mean 0.2 ind. $\mathrm{l}^{-1}$ ). These figures are at least 2 orders of magnitude lower than the concentration used in the experimental jar. However, the fact that daily ration levels derived from in vitro and in situ methods are reasonably similar shows that averaged zooplankton abundances do not reflect the microscale patchiness typical of naturally occurring zooplankton communities (Navorotsky \& Zadonskaya 1991, Nemirovsky et al. 1991). Indeed, to survive on low daily rations of 6.3 to $7.1 \%$ of body dry weight, Themisto gaudichaudi would need to feed on prey concentrations at least an order of magnitude higher than those observed in the net samples.

Themisto gaudichaudi is an active predator exhibiting daily rations that depend on the prey concentration. The species is adapted to sharp fluctuations in food concentration and is able to starve for prolonged periods (Gibbons et al. 1992, Persy 1993). T. gaudichaudi is, therefore, capable of satisfying its feeding demands very rapidly (Gibbons et al. 1992) when aggregations (even microscale swarms) of the appropriate prey type are met. It has also been suggested that consumption becomes independent of prey concentration when prey density exceeds a high threshold (Yamashita et al. 1984, Gibbons et al. 1992). Thus, daily rations of $T$ gaudichaudi can theoretically be even higher than those estimated in situ in our study because of the high degree of prey/predator covariance.

\section{Predation impact}

Since Themisto gaudichaudi adults can consume prey at rates equivalent to at least $6.3 \%$ of their body dry weight per day, they could have a significant impact on the local mesozooplankton communities, especially in regions where hyperiids occur in great abundances. It has been shown that some species of the genus Themisto can have a marked detrimental effect on the seasonal stock of fish eggs and larvae (Siegfried 1965, Sheader \& Evans 1975, Yamashita et al. 1985). Studies on the predation impact by T. gaudichaudi in the Benguela Upwelling System have shown rates in the range of 4 to $38.5 \%$ of copepod standing stock removed per day (Gibbons et al. 1992). These estimates were obtained under the assumption that densities of both prey and amphipods covary closely in time and space. The maximum abundances of $T$. gaudichaudi used ranged between 2.3 and 22.4 ind. $\mathrm{m}^{-3}$. In our study, however, maximum densities of $T$. gaudichaudi adults, averaged over the 0 to 200 (100) m layer, never exceeded 1.5 ind $\mathrm{m}^{-3}$ Consequently, the predation impact was never higher than $2.1 \%$ of the total mesozooplankton standing stock. In terms of daily secondary production consumed, however, this impact was substantial and locally reached levels of $\sim 70 \%$, suggesting that $T$. gaudichaudi adults are at times able to control the mesozooplankton stock in the vicinity of South Georgia. Assuming an assimilation efficiency of $-80 \%$ (Vinogradov \& Shushkina 1987), the contribution of $T$ gaudichaudi to the downward flux of faeces could account for $<0.1$ to $14 \%$ of the mesozooplankton daily secondary production.

The main results of this study show that the hyperiid Themisto gaudichaudi is an important predator of mesozooplankton and is able to contribute significantly to the vertical flux of biogenic carbon. Although, these estimates are quite representative of the average conditions in the natural environment, the potential impact of $T$. gaudichaudi may attain levels much higher than these when the degree of covariance between prey and hyperiid is particularly high, both in time and space

Acknowledgements. This study was funded by the South African Department of Environmental Affairs and Tourism and by Rhodes University (Grahamstown). We are very grateful to the officers and crew of the RV 'Africana' and to many colleagues from the Sea Fisheries Research Institute (SFRI, Cape Town) for their assistance at sea. We are also indebted to Dr H. Verheye of SFRl for granting permission to use unpublished mesozooplankton abundance and biomass data.

\section{LITERATURE CITED}

Atkinson A, Peck JM (1988) A summer-winter comparison of zooplankton in the oceanic area around South Georgia. Polar Biol 8:463-473

Bost CA, Koubbi P, Genevois F, Ruchon L, Ridox V (1994) Gentoo penguin Pygoscelis papua diet as an indicator of planktonic availability in the Kerguelen Islands. Polar Biol $14: 147-153$

Chechun IS (1984) Feeding and trophic relationships of some fish from subantarctic waters of the Indian Ocean. Proc Zool Inst (Leningrad) 127:38-68 (in Russian)

Conover RJ, Durvasula R, Roy S, Wang R (1986) Probable loss of chlorophyll-derived pigments during passage through 
the gut of zooplankton and some of the consequences. Limnol Oceanogr 31:878-887

Dam HG, Peterson WT (1988) The effect of temperature on the gut clearance rate constant of planktonic copepods. J Exp Mar Biol Ecol 123:1-14

Everson I, Ward P (1980) Aspects of Scotia Sea zooplankton Biol $J$ Linnean Soc 14:93-101

Fortier L, Le Fèvre J, Legendre L (1994) Export of biogenic carbon to fish and to the deep ocean: the role of large plankton.ıc microphages. J Plankton Res 16:809-839

Gibbons MJ, Stuart V, Verheye HM (1992) Trophic ecology of carnivorous zooplankton in the Benguella. S Afr J Mar Sci. $12: 421-437$

Hardy AC, Gunther ER (1935) The plankton of the South Georgi.a whaling grounds and adjacent waters, 19261927. Discovery Rep 11:1-456

Hopkins TL (1985) Food web of an Antarctic midwater ecosystem. Mar Biol 89:197-212

Ikeda T (1989) Are Antarctic zooplankton metabolically more cold-adapted than Arctic zooplankton? An intra-generic comparison of oxygen consumption rates. J Plankton Res 11:619-624

Ikeda T; Mitchell AW (1982) Oxygen uptake, ammonia excretion and phosphate excretion by krill and other Antarctic zooplankton in relation to their body size and chemical composition. Mar Biol 71:283-298

Kane JE (1966) The distribution of Parathemisto gaudichaudii (Guer.), with observations on its life-history in the $0^{\circ}$ to $20^{\circ} \mathrm{E}$ sector of the Southern Ocean. Discovery Rep 34:163-198

Kane JE (1967) Observations on the moulting and feeding of a hyperiid amphipod. Crustaceana 6:129-132

Kock KI f., Wilhelms S, Everson I, Gröger J (1994) Variations in the diet composition and feeding intensity of mackerel icefish Champsocephalus gunnari at South Georgia (Antarctic). Mar Ecol Prog Ser 108:43-57

Laval P (1.980) Hyperiid amphipods as crustacean parasitoids associated with gelatinous zooplankton. Oceanogr Mar Biol A Rev 18:11-56

Lopez MDG, Huntley ME, Syles PF (1988) Pigment destruction by Calanus pacificus: impact on the estimation of water column fluxes. J Plankton Res 10:715-734

Mackas D, Bohrer R (1976) Fluorescence analysis of zooplankton gut contents and an investigation of diel feeding patterns. J Exp Mar Biol Ecol 25:77-85

Madin LP, Harbison GR (1977) The associations of Amphipoda Hyperiidea with gelatinous zooplankton. I. Associations with Salpidae. Deep Sea Res 24:449-463

Mayzaud P, Razouls S (1992) Degradation of gut pigment during feeding by a subantarctic copepod: importance of feeding history and digestive acclimation. Limnol Oceanogr 37:393-404

Navorotsky VV, Zadonskaya TA (1991) Fine-scale vertical structure and mesozooplankton in the Subarctic Front (megapolygon). Rep Russ Acad Sci 316(4):983-987 (in Russian)

Nemirovsky MS, Piontkovsky SA, Seregin SA, Korshenko AN (1991) Micro-scale distribution of zooplankton: adequatediffusively processes and behaviour of individuals. In Commercially important investigations of plankton (collected papers). VNIRO Publishers, Moscow, 1:100-111 (in Russian!

Nemoto T, Yoo KI (1970) An amphipod (Parathemisto gaudichaudii) as a food of the Antarctic Sei Whale. Sci Rep Whales Res Inst Tokyo 22:153-158

Pakhomov EA, MCQuaid CD (1996) Distribution of surface zooplankton and seabirds across the Southern Ocean Polar Biol 16 (in press)
Perissinotto R, Pakhomov EA (in press) Gut evacuation rates and pigment destruction in the Antarctic krill Euphausia superba. Mar Biol

Permitin YE. Tarverdieva MI (1972) The food of some Antarctic fish in the South Georgia area. J Ichthyol 12(1): $104-114$

Persy JA (1993) Energy consumption and metabolism during starvation in the Arctic hyperiid amphipod Themisto libe/lula Mandt. Polar Biol 13:549-555

Robertson AA, Alexander DGW, Miller DGM (1981) Modified collapsible opening and closing midwater trawls (RMT-8 and RMT-2). Fish Bull S Afr 14:103-113

Rodhouse PG, White MG, Jones MRR (1992) Trophic relations of the cephalopod Martialia hyadesi (Teuthoidea: Ommastrephidae) at the Antarctic Polar Front, Scotia Sea. Mar Biol 114:415-421

Schneppenheim R, Weigmann-Haass R (1986) Morphological and electrophoretic studies of the genus Themisto (Amiphipoda: Hyperiidea) from the south and north Atlantic. Polar Biol 6:215-225

Sheader M, Evans $F(1975)$ Feeding and gut structure of Parathemisto gaudichaudii (Guérin) (Amphipoda, Hyperiidea). J Mar Biol Ass UK 55:641-656

Siegfried WR (1965) Observations on the amphipod Parathemisto gaudichaudii (Guér.) off the west coast of South Africa. Zool Afr 1(1):339-352

Simard Y, Lacrolx G, Legendre L (1985) In situ twilight grazing rhythm during diel vertical migrations of a scattering layer of Calanus finmarchicus. Limnol Oceanogr 30: $598-606$

Strelnikova VM (1989) Relationship between body weight and length, and caloric content of the Antarctic hyperiid Parathemisto gaudichaudii. Hydrobiol J (Kiev) 25(1): $107-109$ (in Russian)

Strickland JDH, Parsons TR (1968) A practical handbook of seawater analysis. Bull Fish Res Bd Can 167:1-311

Sugisaki $H_{1}$ Terazaki M, Wada E, Nemoto T (1991) Feeding habits of a pelagic amphipod. Themisto japonica. Mar Biol 109:241-244

Torres JJ, Aarset AV, Donnelly J, Hopkins TL, Lancraft TM, Ainley DG (1994a) Metabolism of Antarctic micronektonic crustacea as a function of depth of occurrence and season. Mar Ecol Prog Ser 113:207-219

Torres JJ, Donnelly J, Hopkins TM, Lancraft TM, Aarset AV, Ainley DG (1994b) Proximate composition and overwintering strategies of Antarctic micronektonic crustacea. Mar Ecol Prog Ser 113:221-232

Tseitlin VB (1988) Generative production of water animals. Oceanology 36:493-497

Vinberg GG (1956) Rate of metabolism and food requirements of fish. White Russia University Press, Minsk (in Russian)

Vinogradov ME, Shushkina EA (1987) Functioning of the planktonic communities in the epipelagic zone of the ocean. Nauka Press, Moscow (in Russian)

Williams R, Robins D (1979) Caloric, ash, carbon and nitrogen content in relation to length and dry weight of Parathemisto gaudichaudii (Amphipoda: Hyperiidea) in the north east Atlantic Ocean. Mar Biol 52:247-252

Yamashita Y, Aoyama T, Kitagawa D (1984) Laboratory studies of predation be the hyperiid amphipod Parathemisto japonica on larvae of the japanese sand-eel Ammodytes personatus. Bull Jap Soc Scient Fish 50(7):1089-1093

Yamashita Y, Kitagawa D, Aoyama T (1985) A field study of predation of the hyperiid amphipod Parathemisto japonica on larvae of the japanese sand-eel Ammodytes personatus. Bull Jap Soc Scient Fish 51(10):1599-1607 